\title{
Prevalence and Predictors of Stress among Bankers in Enugu State South-East Nigeria
}

Okwor TJ1, Ndu AC11, Arinze-Onyia $S^{2}$, Ogugua IJ', Obionu IM ${ }^{1}$, Agwu-Umahi OR ${ }^{3}$, Okeke $T A^{1}$, Aguwa EN ${ }^{1,3}$

${ }^{1}$ Department of Community Medicine, University of Nigeria Teaching Hospital, Ituku/Ozalla, Enugu 2Department of Community Medicine, Enugu State University Teaching Hospital, Enugu/College of Medicine, Enugu State University

${ }^{3}$ Department of Community Medicine, College of Medicine, University of Nigeria

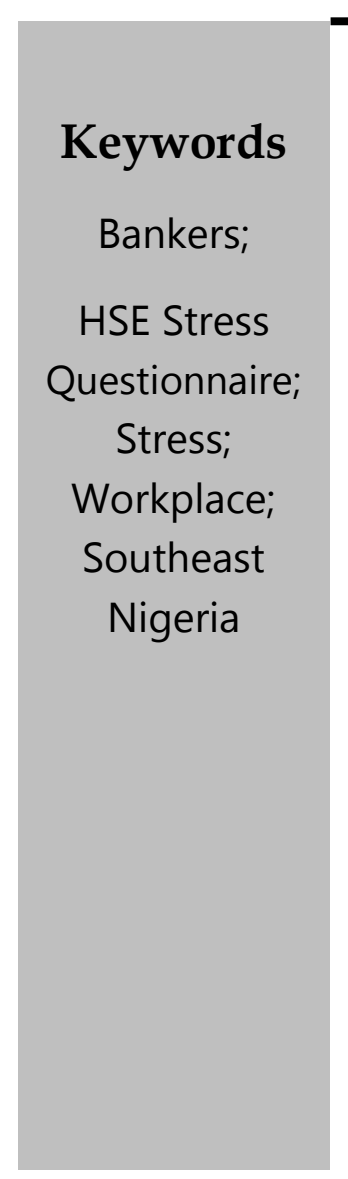

\section{ABSTRACT}

Background: The work environment is rapidly changing and in recent times, occupational stress poses a threat to the health, morale and productivity of workers and the organization. This study sought to determine the prevalence and predictors of stress among bankers in a south-eastern state of Nigeria.

Methods: A descriptive cross-sectional study was carried out among 370 bankers in Enugu State, Nigeria using the Health, Safety, Executive (HSE) management standards indicator tool. Multistage sampling method was used to select participants. Statistical analysis was done using SPSS 22.0. Level of statistical significance was set at $p<0.05$.

Results: The mean age of the participants was $34.54 \pm 6.3$ years while the mean years of work was $6.01 \pm 4.7$ years. One hundred and seventy-four $(47 \%)$ reported high level of stress due to relationship at work while $318(85.9 \%)$ reported low level of stress due to roles. Being 35 years or less was found to a predictor of high (AOR 0.55, CI 0.30-1.02) level of stress due to control.

Work experience of 5 years or less was found to be a predictor of both high (AOR 0.74, CI 0.40--1.37) and low (AOR 0.99, CI 0.40-1.37) levels of stress due to control.

Conclusion: This study has shown that the prevalence of stress was high among bankers in Enugu State, South-East Nigeria. There is, therefore, the need for routine stress assessment and interventions in the banking industry especially for those at high risk.

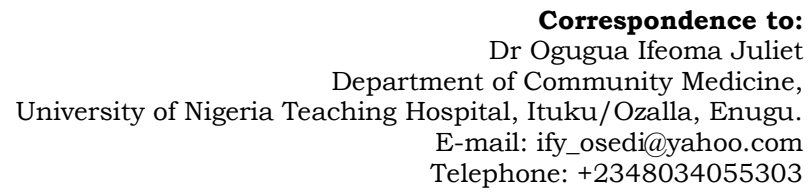

\section{INTRODUCTION}

Workplace stress has been identified as a health and safety risk throughout the world, including in Nigeria. ${ }^{1}$ According to the International Labour Organization (ILO), work-related stress is determined by work organization, work design and labour. ${ }^{1}$ It occurs when the demands of the job do not match or exceed the capabilities, resources, or needs of the worker, or when the knowledge or abilities of an individual worker or group to cope are not matched 
with the expectations of the culture of an enterprise. ${ }^{2}$ According to the National Institute for Occupational Safety and Health (NIOSH) ranking for occupational stress level, banking was listed among the most stressful occupations. ${ }^{3,4}$ It was documented that in these stressful occupations, the employees had insufficient control over the work, with employees feeling that they were trapped in jobs where they were regarded as quasi-machines rather than as people. ${ }^{3}$ Stress can manifest in employee's behaviour in various forms such as depression, anxiety, burnout, headache, frustration, fatigue, aggression and loss of concentration. It can also lead to the use of substances such as alcohol and illicit drugs and possibly abuse of these substances. 5,6

A high level of occupational stress does not only have detrimental effects on the health of the employees but also affects the employee's creativity, morale and productivity. ${ }^{6}$ This is evidenced by studies done among bankers in southwest Nigeria and Pakistan which showed that job stress impacted negatively on the bankers' performances. ${ }^{7,8}$ In the past decade, the banking sector has undergone swift changes in policies due to globalization and liberalization. 5 It has also become more competitive due to the creation of more private sector banks, downsizing and the introduction of new technologies such as mobile and internet banking services, automated teller machine, point of sale (POS) machine, etc. The arrival of these technological advancements in the banking environment has changed the working process for the bank staff and has led to downsizing the workforce in the sector. 5 Furthermore, globalization and privatization led policies have resulted in reforms in the banking sector in order to adjust and provide more competitive services. The implications of these changes have affected the social, psychological and even the economic domains of the bank workers. ${ }^{5}$

Data on work-related stress are available to varying extents across countries and regions; the greater share of research in this field is to be found in developed countries, and to only a limited extent in Africa. ${ }^{2}$ Various mechanisms of coping with stress have been devised by developed countries and people in developing countries like Nigeria are gradually becoming more aware of the effects of work-related stress. However, most developing countries do not have policies in relation to psychosocial risks and work-related stress. ${ }^{9}$ Presently, workplace stress has become a major problem and a matter of concern for employees and employers. Therefore, this study sought to determine the prevalence of workplace stress and its associated factors among bankers in Enugu Metropolis, Nigeria.

\section{METHODOLOGY}

A cross-sectional descriptive study was carried out among bankers in Enugu metropolis in Enugu State south-east Nigeria between November 2017 and February 2018. A minimum sample size of 378 was obtained using the formula for estimating proportion, 10 a prevalence of 
stress of 34\% among bankers in a study in India ${ }^{11}$ and adjusting for $10 \%$ non-response. A multistage sampling technique was used in the study. First, using a simple random sampling method by balloting, five banks were selected from the sixteen banks in Enugu metropolis. From the selected banks, four branches each were further selected using a simple random sampling method. Then all bankers who met the inclusion criteria in each selected branch were recruited for the study.

Ethical clearance was obtained from the Health Research and Ethics Committee of the University of Nigeria Teaching Hospital (UNTH), Enugu. Permission and written informed consent were gotten from the management and staff of all the selected banks, respectively. Confidentiality was maintained throughout the study and the participants were informed that they can withdraw from the study when they so wish.

Data was collected using a pre-tested structured self-administered questionnaire that was adapted from a 35-item Health, Safety, Executive Management Standards Indicator Tool (HSE-MS IT). ${ }^{12}$ Demographic variables like age, sex, occupation, marital status, and years of employment were included in the questionnaire. A study done in Italy confirmed the concurrent and construct validity of the HSE-MS IT and identified the individual contribution of each of its scales in predicting relevant work-related stress outcomes. ${ }^{13}$ It was concluded that HSE-MS IT seems to be a valid instrument for identifying the possible sources of psychosocial risk at work. ${ }^{13}$ Three research assistants were recruited and trained on the objectives of the study and the data collection methods. The questionnaire was pretested in a bank that was not included in the study. Data collection lasted for three months.

The HSE-MS IT indicated the degree to which participant might be feeling stressed and is based on six areas: demands, control, support from managers/support from peers, role, change and relationships. This study assessed the level of work-related stress among bankers based on the following domains: Demand which includes issues such as workload, work patterns and the work environment; Control which involves to what extent one has a say in the way their work is carried out; Support which involves the resources and encouragement provided by the organization, superiors and colleagues; Relationships at work which includes promoting positive work behaviour, avoidance of conflicts and dealing with improper behaviour; Role which deals with peoples' understanding of their function within the organization and to the extent to which the organization ensures that employees do not have conflicting roles and Change involves how organizational change is enforced and managed. For each of the item, the participant indicated using a five-point Likert scale ranging from 'Always' to 'Never' the degree to which he/she might be feeling stressed.

The analysis for each domain of stress was based on the average or mean number of 
questions ticked by a participant. An average of 4-5 indicated low levels of stress, an average score of 3 was categorized as being neutral while an average score of 1-2 indicated high levels of stress. For example, the numbers ticked that corresponded to 'Demands' were added then divided by the total number of 'Demands' questions (8 questions) to give an average for the 'Demands' management standard. ${ }^{12,13}$ A participant scoring an average of 4-5 indicated that this person had few issues about the management standard and hence likely exhibited (in the case of demands) low levels of demand-resource imbalance (low level of stress). An average score of 1-2 indicated that they were likely to already be suffering from high levels of stress due to demand-resource imbalance or be at risk of it. A score of 3 was categorized as neutral. ${ }^{12,13}$

Data was analysed using Statistical Package for Social Science (SPSS) version 22.0. Level of statistical significance was set at $\mathrm{p}<0.05$. Categorical variables were summarized using frequencies and percentages while quantitative variables were summarized using means and standard deviation. Chisquare test was used to determine factors associated with different domains of stress while multivariate analysis was used to determine the predictors of stress.

\section{RESULT}

A total of 370 bankers were studied giving a response rate of $97.8 \%$. Table 1 shows the socio-demographic characteristics of the participants. The mean age was $34.54 \pm 6.3$ years. One hundred and seventy-four (47\%) were males and 196 (53\%) were females. The highest proportion of the participants 207 $(55.9 \%)$ were married, and the mean years of work was $6.01 \pm 4.7$ years.

Table 1: Sociodemographic characteristics of the bankers

\begin{tabular}{lll}
\hline Variables & $\begin{array}{l}\text { Frequency } \\
\text { (n=370) }\end{array}$ & Percent \\
\hline $\begin{array}{l}\text { Age (years) } \\
\leq 35\end{array}$ & 215 & 58.1 \\
$>35$ & 155 & 41.9 \\
Mean age (years) & $34.54 \pm 6.30$ & \\
Sex & & \\
Male & 174 & 47.0 \\
Female & 196 & 53.0 \\
Marital status & & \\
Single & 161 & 43.5 \\
Married & 207 & 55.9 \\
Widowed & 1 & 0.30 \\
Separated/Divorced & 1 & 0.30 \\
Religion & & \\
Christianity & 366 & 98.9 \\
Others & 4 & 1.1 \\
Educational level & & \\
Secondary & 2 & 0.5 \\
Tertiary & 368 & 99.5 \\
Years of Work & & \\
<5 & 203 & 54.9 \\
> 5 & 167 & 45.1 \\
Mean years of work & $6.01 \pm 4.7$ & \\
Department & & 73.5 \\
Operations & 272 & 26.5 \\
Marketing & 98 & \\
\hline Others: Islam and African traditional religion &
\end{tabular}

Others: Islam and African traditional religion

Table 2 shows the participant's response to the questions regarding roles and relationship at work. More than half of the participants 217 (58.6\%) and 202 (54.8\%) reported that they were 'always' clear of their responsibilities at work and their objectives respectively. However, 38(10.3\%) and $31(8.4 \%)$ of the participants reported they were 'sometimes' subjected to personal harassment in the form of unkind words or behaviour and bullying at work respectively. 


\begin{tabular}{|c|c|c|c|c|c|c|}
\hline & $\begin{array}{l}\text { Always } \\
\mathrm{n}(\%)\end{array}$ & $\begin{array}{l}\text { Often } \\
\mathrm{n}(\%)\end{array}$ & $\begin{array}{l}\text { Sometimes } \\
\mathrm{n}(\%)\end{array}$ & $\begin{array}{l}\text { Seldom } \\
\mathrm{n}(\%)\end{array}$ & $\begin{array}{l}\text { Never } \\
\mathrm{n}(\%)\end{array}$ & Total \\
\hline \multicolumn{7}{|l|}{ Role } \\
\hline $\begin{array}{l}\text { I am clear what is expected of me } \\
\text { at work }\end{array}$ & $249(67.2)$ & $79(21.4)$ & $25(6.8)$ & 7 (1.9) & $10(2.7)$ & 370 \\
\hline $\begin{array}{l}\text { I know how to go about getting } \\
\text { my job done }\end{array}$ & $176(47.7)$ & $125(33.9)$ & $41(11.1)$ & $11(3.0)$ & $16(4.3)$ & $369 *$ \\
\hline $\begin{array}{l}\text { I am clear what my duties and } \\
\text { responsibilities are }\end{array}$ & $217(58.6)$ & $92(24.8)$ & $45(12.1)$ & $4(1.1)$ & $11(2.9)$ & 370 \\
\hline $\begin{array}{l}\text { I am clear about the goals and } \\
\text { objectives for my department }\end{array}$ & $202(54.8)$ & $85(23.0)$ & $47(12.7)$ & $17(4.6)$ & $18(4.9)$ & $369 *$ \\
\hline $\begin{array}{l}\text { I understand how my work fits } \\
\text { into the overall aim of the } \\
\text { organization }\end{array}$ & $171(46.2)$ & $104(28.1)$ & $53(14.3)$ & $22(5.9)$ & $20(5.4)$ & 370 \\
\hline \multicolumn{7}{|l|}{ Relationship } \\
\hline $\begin{array}{l}\text { I am subject to personal } \\
\text { harassment in the form of } \\
\text { unkind words or behaviour }\end{array}$ & $38(10.3)$ & $54(14.6)$ & $89(24.1)$ & $66(17.9)$ & $122(33.1)$ & $369 *$ \\
\hline $\begin{array}{l}\text { There is friction or anger } \\
\text { between colleagues }\end{array}$ & $34(9.2)$ & $38(10.3)$ & $151(41.8)$ & $89(24.0)$ & $58(15.6)$ & 370 \\
\hline I am subject to bullying at work & $31(8.4)$ & $37(10.0)$ & $58(15.7)$ & $70(18.9)$ & $174(47.0)$ & 370 \\
\hline $\begin{array}{l}\text { Relationships at work are } \\
\text { strained }\end{array}$ & $27(7.3)$ & $44(11.9)$ & $133(35.9)$ & $90(24.3)$ & $76(20.5)$ & 370 \\
\hline
\end{tabular}

*Non-response present

Table 3 shows the participant' response to the components of change and demand at work. Forty-eight (12.9\%) reported that they 'never' had sufficient opportunities to question managers about changes at work and only 31 (8.4\%) knew how changes made at their workplace will work out in practice. Seventy-nine $(21.4 \%)$ and $32(8.6 \%)$ of the participants reported that they 'always' had unachievable deadline and were unable to take sufficient breaks respectively. Table 4 shows the participants' responses regarding the components of control and support at work. Ninety-four (25.4\%) reported that they 'never' had flexible working time while 25 $(6.8 \%)$ reported that they 'never' had a say in their work speed. Ninety-one $(24.6 \%)$ of the participants reported they were 'always' given supportive feedback on the work they did, however, 45 (12.2\%) reported they were 'never' supported through emotionally demanding work.
Table 5 shows the prevalence of stress for the different domains. One hundred and seventy-four (47\%) and 170 (45.9\%) of the participants had a high level of stress due to relationship and support at work, respectively. Majority of the participants had a neutral level of stress in these domains; demand 251(67.8\%), control 239 (64.6\%) and support 195 (52.7\%). A higher proportion, 318 (85.9\%) experienced a low level of stress due to work roles. Table 6 shows the factors associated with each stress domain. No socio-demographic factors were found to be associated with stress due to demand, relationship, role, support and change. However, less than 5 years of work experience $\left(x^{2}=7.146\right.$, $\mathrm{p}=0.028$ ) and being less than 35 years of age $\left(x^{2}=11.830, p=0.003\right)$ were associated with stress due to control. Table 7 shows the predictors of stress due to control. Predictors of high levels of stress due to 


\begin{tabular}{|c|c|c|c|c|c|c|}
\hline & Always & n $(\%)$ & Sometimes & Seldom & $\begin{array}{l}\text { Never } \\
\mathrm{n}(\%)\end{array}$ & Total \\
\hline \multicolumn{7}{|l|}{ Change } \\
\hline $\begin{array}{l}\text { I have sufficient } \\
\text { opportunities to question } \\
\text { managers about change at } \\
\text { work }\end{array}$ & $69(18.6)$ & $80(21.6)$ & $116(31.4)$ & $57(15.4)$ & $48(12.9)$ & 370 \\
\hline $\begin{array}{l}\text { Staff are always consulted } \\
\text { about change at work }\end{array}$ & $60(16.2)$ & $87(23.5)$ & $131(35.4)$ & $56(15.1)$ & $36(9.7)$ & 370 \\
\hline $\begin{array}{l}\text { When changes are made at } \\
\text { work, I am clear how they } \\
\text { will work out in practice }\end{array}$ & $31(8.4)$ & $29(7.8)$ & $134(36.2)$ & $110(29.7)$ & $66(17.8)$ & 370 \\
\hline \multicolumn{7}{|l|}{ Demand } \\
\hline $\begin{array}{l}\text { Different groups at work } \\
\text { demand things from me that } \\
\text { are hard to combine }\end{array}$ & $39(10.5)$ & $66(17.9)$ & $157(42.4)$ & $52(14.1)$ & $56(15.1)$ & 370 \\
\hline I have unachievable deadline & $79(21.4)$ & $77(20.8)$ & $123(33.2)$ & $55(14.9)$ & $36(9.7)$ & 370 \\
\hline $\begin{array}{l}\text { I have to work very } \\
\text { intensively }\end{array}$ & $12(3.2)$ & $19(5.1)$ & $81(21.9)$ & $122(32.9)$ & $136(36.7)$ & 370 \\
\hline $\begin{array}{l}\text { I have to neglect some tasks } \\
\text { because I have too much to } \\
\text { do }\end{array}$ & $52(14.1)$ & $62(16.8)$ & $141(38.1)$ & $62(16.8)$ & $53(14.3)$ & 370 \\
\hline $\begin{array}{l}\text { I am unable to take } \\
\text { sufficient breaks }\end{array}$ & $32(8.6)$ & $61(16.4)$ & $142(38.4)$ & $69(18.6)$ & $65(17.6)$ & 370 \\
\hline $\begin{array}{l}\text { I am pressured to work long } \\
\text { hours }\end{array}$ & $34(9.2)$ & $63(17.0)$ & $104(28.1)$ & $93(25.1)$ & $76(20.5)$ & 370 \\
\hline I have to work very fast & $44(11.9)$ & $23(6.2)$ & 70 (18.9) & $92(24.8)$ & $141(38.1)$ & 370 \\
\hline $\begin{array}{l}\text { I have unrealistic time } \\
\text { pressures }\end{array}$ & $46(12.4)$ & $54(14.6)$ & $154(41.6)$ & $84(22.7)$ & $32(8.6)$ & 370 \\
\hline
\end{tabular}

control were 5 years or less of work experience (AOR 0.74, CI 0.40-1.37) and being 35 years or less (AOR 0.55, CI 0.301.02). Work experience of 5 years or less (AOR 0.99, CI 0.40-1.37) was also found to be a predictor of low levels of stress due to control.

\section{DISCUSSION}

Occupational stress which has been called the "21st Century disease" is a serious problem for professionals whose work demands intense involvement with clients. ${ }^{11}$ Stressors at the workplace could be as a result of the nature of the job or context of the job and include an unclear requirement, role overload, high-stress times with no downtimes, poor communication, lack of personal control, role conflict, lack of recognition and poor leadership. ${ }^{14}$ Findings from this study revealed differences in the level of stress in the different domains; demand, control, support, relationship, role and change. A higher proportion of the participants reported a high degree of workrelated stress due to relationship and support from colleagues and employees at work.

The poor relationship at work might be due to harassment and bullying as some of the participants reported that they were 'always' harassed and bullied at their workplace. Bullying at the workplace has been reported as a major stressor that could lead to physical or mental health issues and low job performance among bank employees thereby decreasing the probability of 
achieving goals. ${ }^{15,16}$ Support was found in our study to cause a high level of stress among the participants. The reason might be due to poor managerial and peer support on emotionally demanding jobs as reported by some participants. This finding was similar to studies done in Pakistan and Nigeria that reported a lack of administrative and social support from colleagues $^{17}$ as well as poor interpersonal relations as stressors among bankers.17,18 Lack of social/organisational support at work was reported to have harmful effect on perceived health, affecting the work-life balance of the employees in financial institutions ${ }^{19,20}$ and led to reduced job performance. ${ }^{17}$ Some studies on stress done among bankers in Nigeria reported work overload and time pressure as stressors at work. ${ }^{18,21}$ However, high level of stress due to demand was found to be low in our present study. This may be so since the majority of the participants were from the operations department and fewer from the marketing department as they always work under pressure to achieve their targets. In our study, the majority of the participants had a low level of stress from role ambiguity and this might be because they were clear on their job description and their responsibilities. This is a very important finding as job anxiety usually becomes higher when the role of an employee is not understood and may lead to a decrease in job performance. ${ }^{22}$ However, a study done in Pakistan reported role ambiguity as a job stressor which led to job dissatisfaction among employees of the banking sector and this might be because their roles were poorly defined. ${ }^{23}$ Workplace stress generally has been shown to have serious public health implications on the employee and the organization. ${ }^{9}$ These include poor physical and mental health which in turn can lead to poor performance and productivity at work. ${ }^{9}$ It can also lead to increased absenteeism, decrease commitment to work, high rate of staff turnover, increase complaints from clients and customers and damage to the organization's image both among its workers and externally. ${ }^{9}$ Studies done among bankers in Nigeria and Pakistan found that stress is a major cause of burnout among bank employees. ${ }^{6,24}$ Effects of stress on the bank employees and the organization were reported by other studies done in Nigeria. These include; anxiety, sleeplessness, hypertension, job dissatisfaction, poor working relationship with colleagues and low productivity and intension to quit.18,25 Age has been reported in some studies to influence stress among bankers. A study done in Kenya noted that older employees (35 years and above) experienced more role stress than younger employees (less than 35 years). ${ }^{26}$ This might be because older employees may not have the strength to cope with work pressure and long working hours. In our present study, being a younger banker ( $<35$ years) was found to be statistically significantly associated with a high level of stress due to control. 


\begin{tabular}{|c|c|c|c|c|c|c|}
\hline & $\begin{array}{l}\text { Always } \\
\mathrm{n}(\%)\end{array}$ & $\begin{array}{l}\text { Often } \\
\mathrm{n}(\%)\end{array}$ & $\begin{array}{l}\text { Sometimes } \\
\mathrm{n}(\%)\end{array}$ & $\begin{array}{l}\text { Seldom } \\
\mathrm{n}(\%)\end{array}$ & $\begin{array}{l}\text { Never } \\
\mathrm{n}(\%)\end{array}$ & Total \\
\hline \multicolumn{7}{|l|}{ Control } \\
\hline $\begin{array}{l}\text { I can decide when to take a } \\
\text { break }\end{array}$ & 72 (19.5) & $56(15.1)$ & $129(34.9)$ & $56(15.1)$ & 57 (15.4) & 370 \\
\hline $\begin{array}{l}\text { I have a say in my own work } \\
\text { speed }\end{array}$ & $92(24.8)$ & $112(30.3)$ & $94(25.4)$ & $47(12.7)$ & $25(6.8)$ & 370 \\
\hline $\begin{array}{l}\text { I have a choice in deciding how I } \\
\text { do my work }\end{array}$ & $63(17.0)$ & $84(22.7)$ & $108(29.2)$ & $66(17.8)$ & 49 (13.2) & 370 \\
\hline $\begin{array}{l}\text { I have some say over the way I } \\
\text { work }\end{array}$ & $60(16.2)$ & 87 (23.5) & $131(35.4)$ & $56(15.1)$ & $36(9.7)$ & 370 \\
\hline My working time can be flexible & $31(8.4)$ & 55 (14.9) & $135(36.5)$ & 55 (14.9) & $94(25.4)$ & 370 \\
\hline $\begin{array}{l}\text { If work gets difficult, my } \\
\text { colleagues will help me }\end{array}$ & $68(18.4)$ & 85 (23.0) & $150(40.5)$ & $46(12.4)$ & $21(5.7)$ & 370 \\
\hline $\begin{array}{l}\text { I am given supportive feedback } \\
\text { on the work I do }\end{array}$ & 91 (24.6) & $108(29.2)$ & $116(31.4)$ & $41(11.1)$ & $14(3.8)$ & 370 \\
\hline $\begin{array}{l}\text { I can rely on my line manager to } \\
\text { help me out with a work problem }\end{array}$ & 79 (21.4) & 87 (23.5) & 137 (37.0) & 49 (13.2) & $18(4.9)$ & 370 \\
\hline $\begin{array}{l}\text { I get help and support I need } \\
\text { from colleagues }\end{array}$ & 97 (26.2) & $91(24.6)$ & 139 (37.6) & 32 (8.6) & $11(2.9)$ & 370 \\
\hline $\begin{array}{l}\text { I receive the respect at work I } \\
\text { deserve from my colleagues }\end{array}$ & $104(28.1)$ & 109 (29.5) & $116(31.4)$ & 24 (6.5) & 17 (4.6) & 370 \\
\hline $\begin{array}{l}\text { I can talk to my line manager } \\
\text { about something that has upset } \\
\text { or annoyed me about work }\end{array}$ & $89(24.1)$ & $77(20.8)$ & $128(34.6)$ & $49(13.2)$ & 27 (7.3) & 370 \\
\hline $\begin{array}{l}\text { I am supported through } \\
\text { emotionally demanding work }\end{array}$ & $46(12.4)$ & 91 (24.6) & $126(34.1)$ & $62(16.8)$ & 45 (12.2) & 370 \\
\hline $\begin{array}{l}\text { My line manager encourages } \\
\text { me at work }\end{array}$ & $113(30.5)$ & $99(26.8)$ & $101(27.3)$ & $31(8.4)$ & $26(7.0)$ & 370 \\
\hline
\end{tabular}

This finding was similar to a study done in Italy which showed that the oldest group (>50 years) gave a higher score for control than those younger than 30 years. ${ }^{27}$ This may have been observed because the younger workers may be less experienced and therefore had anxiety from job expectations. It could also be because emotional workload in younger people was shown to be associated with a higher risk of mental health complaints. ${ }^{28}$

Table 5: Prevalence of stress among bankers

\begin{tabular}{lccc}
\hline Domains & $\begin{array}{c}\text { High } \\
\mathrm{n}(\%)\end{array}$ & $\begin{array}{c}\text { Neutral } \\
\mathrm{n}(\%)\end{array}$ & $\begin{array}{c}\text { Low } \\
\mathrm{n}(\%)\end{array}$ \\
\hline Demand & $22(5.9)$ & $251(67.8)$ & $97(26.2)$ \\
Control & $84(22.7)$ & $239(64.6)$ & $47(12.7)$ \\
Support & $170(45.9)$ & $195(52.7)$ & $5(1.4)$ \\
Relationship & $174(47.0)$ & $142(38.4)$ & $54(14.6)$ \\
Role & $7(1.9)$ & $45(12.2)$ & $318(85.9)$ \\
Change & $73(19.7)$ & $173(46.8)$ & $124(33.5)$ \\
\hline $\mathbf{n = 3 7 0}$ & & &
\end{tabular}

The younger age found to be associated with a high level of stress due to control could also explain the relationship between less than 5 years' work experience as a factor also found to be associated with a high level of stress due to control. These association of younger age and less than 5 years working experience with stress due to control could be due to lack of involvement of younger and new employees in organizational decision making as reported by some participants in the study. Less than 5 years' work experience also found to be associated with a low level of stress due to control might be due to less work/time pressure as they may not have been given many responsibilities. A study done in Kenya showed that bankers who have worked for 16 years and above had more job autonomy than employees 
who have worked in the banks for less than 16 years. ${ }^{26}$ This could be possible as employees who had worked in the banks for 16 years and above may have risen the organisational ranks through promotions into positions that allow them the freedom to make decisions and to use their initiatives to achieve results. ${ }^{26}$

Limitation: Firstly, this study was done only among bankers in Enugu Metropolis therefore, the finding might not be generalised to other bankers in rural communities and other states in Nigeria. Therefore, there is a need for further studies involving bankers in other states. Secondly, the responses were self-reported based on how they felt in the last 6 months before the study and this may not be entirely true. Thirdly, the tool (HSE-MIT) has not been validated in our environment. However, it was pre-tested and had been previously adapted by some researchers. ${ }^{29-33}$

Conclusion: Our finding has shown that the prevalence of stress among bankers in Enugu Metropolis Nigeria is high. Being in the younger age group ( $<35$ years) and having less than 5 years of work experience were noted as predictors of stress. Workrelated stress is a prevalent issue and of significant public health importance particularly in the banking environment as seen from this study. These findings may influence development and implementation of occupational health policies which address psychosocial work hazards such as stress and also used as a baseline for implementation of interventions addressing work-related stress. There is a need for qualitative research to explore more issues related to work-related stress.

Acknowledgement: We would like to thank all the bankers that participated in this study despite their busy schedule.

Conflict of Interest: None

\section{Authors' Contribution:}

Conception and design of the study: OTJ, NAC, OTA, AEN, ASU, AO, OIJ, OIM

Collection of data: OIJ, OIM, OTJ, AO

Collation and analysis of data: ASU, AO, OTJ, NAC, OTA, AEN, OIJ, OIM

Drafting and revision of the manuscript: OTJ, NAC, OTA, AEN, OIJ, OIM, ASU, AO

Read and approved the final manuscript: All authors.

\section{REFERENCES}

1. International Labour Organization. Occupational injuries statistics from household surveys and establishment surveys An ILO manual on methods [Internet]. 2013 [cited 2019 Nov 11]. p. 12. Available from:

https://www.ilo.org/africa/mediacentre/news/WCMS_477712/lang-en/index.htm

2. International Labour Organization. International Labour Organization (ILO)Workplace stress: A collective challenge. [Internet]. 2012 [cited 2019 Nov 11]. Available from: https://www.ilo.org/africa/mediacentre/news/WCMS_477712/lang-en/index.htm. 
Table 6: Factors associated with stress due to control

\begin{tabular}{|c|c|c|c|c|c|}
\hline Variable & $\begin{array}{l}\text { High level } \\
\text { n (\%) }\end{array}$ & $\begin{array}{l}\text { Low level } \\
\text { n (\%) }\end{array}$ & $\begin{array}{l}\text { Neutral } \\
\text { n (\%) }\end{array}$ & Chi square & P value \\
\hline \multicolumn{6}{|l|}{ Age (years) } \\
\hline$\leq 35$ & 35 (16.5) & $32(15.1)$ & $145(68.4)$ & 11.830 & $0.003 *$ \\
\hline$>35$ & $48(31.4)$ & $15(9.8)$ & $90(58.8)$ & & \\
\hline \multicolumn{6}{|l|}{ Sex } \\
\hline Male & $38(21.8)$ & 19 (10.9) & $117(67.2)$ & 1.286 & 0.526 \\
\hline Female & 46 (23.5) & $28(14.3)$ & $122(62.2)$ & & \\
\hline \multicolumn{6}{|c|}{ Marital status } \\
\hline Not Married & $28(17.2)$ & 21 (12.9) & $114(69.9)$ & 5.213 & 0.074 \\
\hline Married & $56(27.1)$ & 26 (12.6) & $125(60.4)$ & & \\
\hline \multicolumn{6}{|l|}{ Religion } \\
\hline Christianity & $83(22.7)$ & 47 (12.8) & $236(64.5)$ & $0.591 \mathbf{F}$ & 0.744 \\
\hline Others & $1(25.0)$ & $0(0.0)$ & $3(75.0)$ & & \\
\hline \multicolumn{6}{|c|}{ Educational level } \\
\hline Secondary & $0(0.0)$ & $0(0.0)$ & $2(100.0)$ & $1.094 \mathbf{F}$ & 0.579 \\
\hline Tertiary & $83(22.6)$ & $47(12.8)$ & $237(64.6)$ & & \\
\hline \multicolumn{6}{|c|}{ Years of work } \\
\hline$\leq 5$ & 35 (17.5) & $29(14.5)$ & $136(68.0)$ & 7.146 & $0.028 *$ \\
\hline$>5$ & $48(29.1)$ & 18 (10.9) & $99(60.6)$ & & \\
\hline
\end{tabular}

Table 7: Multinomial regression analysis for the predictors of stress due to control

Predictor variable $\quad$ p-value $\quad$ AOR $\quad 95 \%$ CI for OR

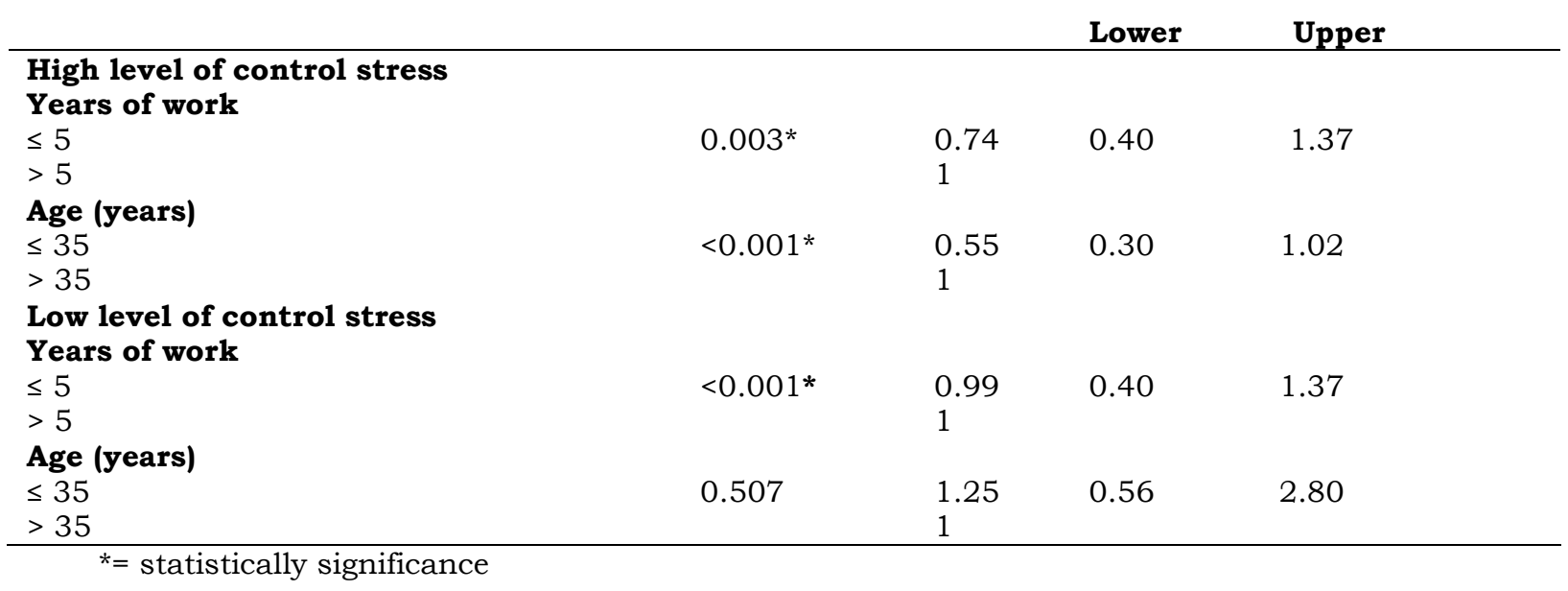

3. National Institute for Occupational Safety and Health (NIOSH). Work organization and stress-related disorders program. 2016.

4. Michailidis M, Yiota G. Employee occupational stress in banking. Work. 2005; 4(24): 123-137.

5. Mahalakshmi S, Jawahar Rani K. Stress management with special reference to public sector bank employees in Chennai Rajendran. Int J Enterp Innov Manag Stud. 2010; 1(3): 322-487.

6. Aguwa EN, Nduka I, Arinze-Onyia SU. Assessment of burnout among health workers and bankers in Aba-south Local Government Area, Abia State, South-East
Nigeria. Niger J Clin Pract. 2014; 17(3): 296302 .

7. Ajayi S. Effect of stress on employee performance and job satisfaction: A case study of Nigerian banking industry [Internet]. SSRN Electronic Journal. Elsevier BV; 2018 [cited 2019 Nov 11]. Available from: https:/ / ssrn.com/abstract=3160620

8. Shahid MN, Latif $K$. Work stress and employee performance in banking sector: Evidence from District Faisalabad, Pakistan. Asian J Bus Manag Sci. 2013;1(7): 38-47.

9. World Health Organization. Protecting Workers' Health Series No. 5 Preventing musculoskeletal disorders in the workplace. WHO. World Health Organization; 2015. 
10. Onwasigwe C. Principles and Methods of Epidemiology. 2nd ed. Enugu: EL 'Damak Publications; 2010. 147 p.

11. Katyal S, Katyal R. Prevalence of occupational stress among bankers. Int $\mathrm{J}$ Humanit Soc Sci Invent. 2013; 2(4): 53-56.

12. HSE Management Standards Indicator Tool. Practical Use of the HSE Management Standards Indicator Tool. [Internet]. [cited 2020 April 11] Available from https://timelesstime.co.uk/knowledgebase Lpractical-use-of-the-hse-managementstandards-indicator-tool/.

13. Marcatto F, Colautti L, Larese Filon F, Luis O, Ferrante D. HSE Management Standards Indicator Tool: concurrent and construct validity. Occupational Medicine, 2014; 64 (5): 365-371

14. Shakya A, Devi VR. Work Stress in Banking Sector: An Empirical Study. Management Insight. 2016; 12(2): 40-50.

15. Faran R. Impact of workplace bullying on job performance and job stress. Journal of Management Information. 2018; 5(3): 12-15

16. Khalique M. Arif I, Siddiqui M, Kazmi, SW. Impact of workplace bullying on job performance, intention to leave, OCB and stress. Pakistan Journal of Psychological Research, 2018; 33(1): 1-26

17. Ehsan M, Ali K. The impact of work stress on employee productivity: Based in the banking sector of Faisalabad, Pakistan. International Journal of Innovation and Economic Development, 2019; 4(6): 32-50

18. Mbanefo PC, Ngige CD, Mojekeh MO. Effect of job stress on employee performance in selected banks in Nigeria. Scholars Journal of Economics, Business and Management, 2019; 6 (1): 55-62

19. Silva LS, Barreto SM. Stressful working conditions and poor self-rated health among financial services employees. Rev. Saúde Pública. 2012; 46: 407-441.
20. Pathak RR. Work-Life Balance in Nepalese commercial banks. Journal of Business and Social Sciences, 2018; 2: 116-124

21. Oginni B, Afolabi G, Erigbe P. The place of job stress in labour turnover of the banking sector in the Nigerian economy. International Journal of Business and Management Invention. 2013; 2(1): 93-99.

22. Nygaard A, Dahlstrom R. Role stress and effectiveness in horizontal alliances. Journal of Marketing. 2002; 66(2): 61-82.

23. Khattak MA, Urooj SF, Khattak J, Iqbal N. Impact of role ambiguity on job satisfaction: Mediating role of job stress. International Journal of Academic Research in Business and Social Sciences,2011; 1(3): 516-531

24. Khattak JK, Khan MA, Ayaz HU, Arif M, Minhas AA. Occupational stress and burnout in Pakistan's banking sector African Journal of Business Management,2011; 5(3): 810-817

25. Olatona FA, Ezeobika EN, Okafor IP, Owoye OBA. Work-related stress and coping mechanisms among bankers in Lagos, Nigeria. African Journal of Medicine and Medical Sciences, 2014; 43: 59-65

26. Ngigi EW, Kipkebut JE. Effect of employee demographic characteristics and job characteristics on job satisfaction among employees in the banking industry: A case of commercial banks in Nakuru Town, Kenya. Journal: International Journal of Management and Information Technology, 2014; 9(3): 1678-1711

27. Marinaccio A, Ferrante $\mathrm{P}$, Corfiati M, Di Tecco C, Rondinone BM, Bonafede M, et al. The relevance of socio-demographic and occupational variables for the assessment of work-related stress risk. BMC Public Health. 2013 Dec 10; 13(1): 1157.

28. Zoer I, Ruitenburg MM, Botje D, FringsDresen MHW, Sluiter JK. The associations between psychosocial workload and mental health complaints in different age groups. Ergonomics. 2011; 54(10): 943-952. 
29. Li X, Kan D, Liu L, Shi M, Wang Y. The Mediating Role of Psychological Capital on the Association between Occupational Stress and Job Burnout among Bank Employees in China. Int. J. Environ. Res. Public Health 2015; 12: 2984-3001

30. Bartram DJ, Yadegarfar G, Baldwin DS. Psychosocial working conditions and workrelated stressors among UK veterinary surgeons. Occupational Medicine, 2009; 59: 334-341.
31. Kerr R, McHugh M, McCrory M. HSE management standards and stress-related work outcomes. Occupational Medicine, 2009; 59: 574-579.

32. Edwards JA, Webster S, Van Laar D, Easton S. Psychometric analysis of the UK Health and Safety Executive's Management Standards and work-related stress Indicator Tool. Work and Stress, 2008; 22: 96-107.

33. Magnavita N. Validation of the Italian version of the HSE Indicator Tool. Occupational Medicine, 2012; 62: 288-294. 